\title{
Pemberdayaan Masyarakat pada Budi Daya dan Pengembangan Produk Pohon Gaharu (Aquilaria sp.) di Kabupaten Tolitoli, Sulawesi Tengah
}

\section{(Community Empowerment in Gaharu (Aquilaria sp.) Tree Cultivation and Product Development in Tolitoli District, Central Sulawesi)}

\author{
Triadiati Triadiati*, Miftahudin \\ ${ }^{1}$ Departemen Biologi, Fakultas Matematika dan Ilmu Pengetahuan Alam, Institut Pertanian Bogor, \\ Kampus IPB Darmaga, Bogor 16680. \\ *Penulis korespondensi: triadiati@apps.ipb.ac.id \\ Diterima Desember 2020/Disetujui Mei 2021
}

\begin{abstract}
ABSTRAK
Kabupaten Tolitoli mempunyai potensi pohon gaharu di hutan alam, tetapi belum dimanfaatkan dan dilestarikan secara optimal oleh masyarakat lokal. Oleh karena itu diperlukan upaya untuk meningkatkan pemahaman dan keterlibatan masyarakat pada budidaya dan pengembangan produk pohon gaharu. Tujuan kegiatan ini adalah: melakukan eksplorasi spesies pohon gaharu dan sumber inokulum lokal dengan metode purposive sampling untuk produksi gaharu, menilai kesesuaian agroklimat untuk budidaya pohon gaharu, melakukan pelatihan secara tatap muka dan praktek pembibitan serta bio-induksi pohon gaharu dengan cara suntikan, serta mengidentifikasi kondisi sosial ekonomi untuk pemberdayaan masyarakat Kabupaten Tolitoli dalam pengembangan produk gaharu dan budidaya pohon gaharu. Metode pelaksanaan dengan cara melakukan eksplorasi dan identifikasi keberadaan pohon gaharu alam dan petani gaharu, pelatihan, dan pendampingan. Hasil eksplorasi dan identifikasi menunjukkan bahwa Kabupaten Tolitoli mempunyai sumberdaya alam berupa pohon-pohon gaharu di hutan dan inokulum lokal untuk bio-induksi pembentukan gaharu. Selain itu, masyarakat setempat yang meliputi Pemda, praktisi, petani, dan institusi pendidikan mempunyai minat dan keinginan yang besar untuk pengembangan produk dan budidaya pohon gaharu. Dengan demikian dapat disimpulkan bahwa pemberdayaan masyarakat untuk pengembangan produk dan budidaya pohon gaharu di Kabupayen Tolitoli dapat terlaksana.
\end{abstract}

Kata kunci: aquilaria, fusarium, induksi gaharu, inokulum lokal

\begin{abstract}
Tolitoli District has a potential for agarwood trees in the forests, but it has not been optimally utilized and preserved by the local communities. Therefore, efforts are needed to increase understanding and community involvement in cultivation and product development of agarwood trees. The objectives of this activity are: to explore agarwood tree species in the forest and sources of local inoculums using a purposive sampling method for agarwood production, to assess the suitability of agro-climates for agarwood tree cultivation, to conduct faceto-face training and practice for agarwood tree breeding and bio-induction by injection, and to identify socioeconomic conditions to support agarwood tree cultivation for community empowerment through product development and cultivation in Kabupaten Tolitoli. The project was implementated by exploring and identifying the existence of natural agarwood trees and agarwood farmers, training, and mentoring. The results of exploration and identification showed that Kabupaten Tolitoli has natural resources of agarwood trees in the forest and local inoculums for the bio-induction of agarwood formation. Also, the local community, including the local government, practitioners, farmers, and educational institutions, have great interest and desire for product development and cultivation of agarwood trees. Thus, it can be concluded that community empowerment through product development and cultivation of agarwood trees in Kabupaten Tolitoli can be implemented.
\end{abstract}

Keywords: aquilaria, agarwood induction, fusarium, local inoculums

\section{PENDAHULUAN}

Gaharu atau gubal gaharu (agarwood, eaglewood, aloeswood) merupakan hasil hutan bukan kayu yang berupa damar wangi (aromatik resin) dari pohon Aquilaria spp. dan genus lain dari famili Thymelaeaceae (Whitmore 1980; BSN 1999). Gaharu merupakan bahan dasar dalam 
industri parfum, dupa untuk berbagai ritual keagamaan, kosmetik dan obat-obatan (Barden et al. 2000). Gaharu dihasilkan oleh pohon Aquilaria sp. dan Gyrinops sp. yang merupakan pohon khas Indomalaya. Keanekaragamannya sangat tinggi dengan enam species Aquilaria, yaitu $A$. malaccensis, A. microcarpa, A. cumingiana, A. beccariana, A. Hirta, dan A. filaria tersebar di wilayah barat serta dua spesies Gyrinops, yaitu $G$. verstegii dan $G$. lendermanii tersebar di wilayah timur Indonesia. Senyawa gaharu terbentuk sebagai respons pertahanan pohon gaharu terhadap berbagai gangguan seperti pelukaan, infeksi patogen, atau perlakuan senyawa kimia (Nobuchi \& Siripatanadilok 1991). Pertahanan dapat bersifat pasif, yaitu pertahanan sudah ada sebelum datangnya gangguan dan bersifat aktif, yaitu pertahanan yang dipicu oleh datangnya gangguan (Goodman et al. 1986; Agrios 2005).

Eksploitasi secara besar-besaran menempatkan A. malaccensis dan A. microcarpa serta $G$. verstegii dalam kategori langka (International Union of Conservation Nation (IUCN) red list), sehingga konservasi keanekaragaman plasma nutfah gaharu perlu dilakukan. Pada tahun 1994, konvensi CITES (Convention on International Trade in Endangered Species) di Amerika Serikat menetapkan bahwa pohon gaharu spesies $A$. malaccensis masuk ke dalam Appendix II, yaitu tanaman yang dibatasi perdagangannya. Penetapan tersebut dikarenakan populasi tanaman penghasil gaharu semakin menyusut di alam yang disebabkan para pengusaha gaharu tidak dapat mengenali dengan tepat tanaman yang sudah mengandung gaharu dan siap dipanen. Pada tahun 2004, Indonesia mengajukan agar semua penghasil gaharu alam yaitu, genus Aquilaria dan Gyrinops dimasukkan ke dalam daftar Appendix II untuk membatasi perdagangannya, sehingga perdagangan gaharu harus memiliki izin dari CITES dan dalam kuota tertentu.

Selain harus dikonservasi, gaharu harus diproduksi dari hasil budi daya untuk menjaga kelestarian alam sekaligus keberlanjutan ekspor. Sampai saat ini pemerintah daerah beberapa provinsi yang merupakan daerah sebaran alami gaharu telah merealisasikan program penanaman gaharu. Salah satu daerah yang mempunyai potensi pohon gaharu adalah Kabupaten Tolitoli, Sulawesi Tengah, tetapi kegiatan eksplorasi keberadaaan spesies pohon gaharu dan pemberdayaan masyarakat untuk budi daya dan pengembangan produk gaharu di sana belum pernah dilakukan.
Produksi gaharu pada pohon-pohon budi daya memerlukan teknologi dengan menggunakan agen penginduksi. Lembaga penelitian dan perguruan tinggi telah melaksanakan penelitian rekayasa bio-induksi gaharu menggunakan agen penginduksi (inokulum) lokal. Teknologi ini digunakan untuk mempersingkat waktu produksi gaharu. Paket teknologi ini sudah mulai dialihkan ke masyarakat, tetapi di Kabupaten Tolitoli teknologi ini belum dikenal oleh masyarakat. Berdasar uraian di atas, ada beberapa permasalahan tentang gaharu di Kabupaten Tolitoli, yaitu belum ada 1) Eksplorasi keberadaan spesies pohon gaharu dan agen penginduksi (inokulum) lokal; 2) Data agroklimat untuk kesesuaian budi daya pohon gaharu; dan 3) Data tingkat pemahaman, pengetahuan, dan sosial ekonomi masyarakat setempat yang berkaitan dengan budi daya dan pengembangan produk gaharu.

Tujuan kegiatan ini adalah: 1) Melakukan eksplorasi spesies pohon gaharu dan sumber inokulum lokal untuk produksi gaharu; 2) Menilai kesesuaian agroklimat untuk budidaya pohon gaharu; 3) Melakukan pelatihan dan praktik pembibitan dan bio-induksi pohon gaharu; dan 4) Mengidentifikasi kondisi sosial ekonomi untuk pemberdayaan masyarakat Kabupaten Tolitoli dalam pengembangan produk gaharu dan budi daya pohon gaharu.

\section{METODE PELAKSANAAN KEGIATAN}

\section{Waktu, Lokasi dan Waktu Kegiatan.}

Tahun 2013: studi kelayakan, 2014-2016: eksplorasi (plasma nutfah gaharu, patogen lokal, dan kondisi sosial ekonomi masyarakat), pengolahan dan analisis data hasil eksplorasi, pelatihan pembibitan dan induksi pembentukan gaharu pada masyarakat lokal, praktik pembibitan dan induksi menggunakan plasma nutfah dan pohon lokal, monitoring dan evaluasi hasil pelatihan, serta praktik. Tahun 2017-2018: komunikasi informal dengan petani gaharu setempat.

Lokasi kegiatan difokuskan di Kecamatan Baolan dan Lampasio, Kabupaten Tolitoli, Provinsi Sulawesi Tengah dengan koordinat $0,35^{\circ}-1,20^{\circ}$ LU dan $120^{\circ}-122,09^{\circ}$ BT (Gambar 1). Analisis tanah diakukan di Balai Penelitian Tanah, Balitbangtan, Kementrian Pertanian. Isolasi dan identifikasi cendawan lokal untuk sumber inokulum dilakukan di Laboratorium IPB 


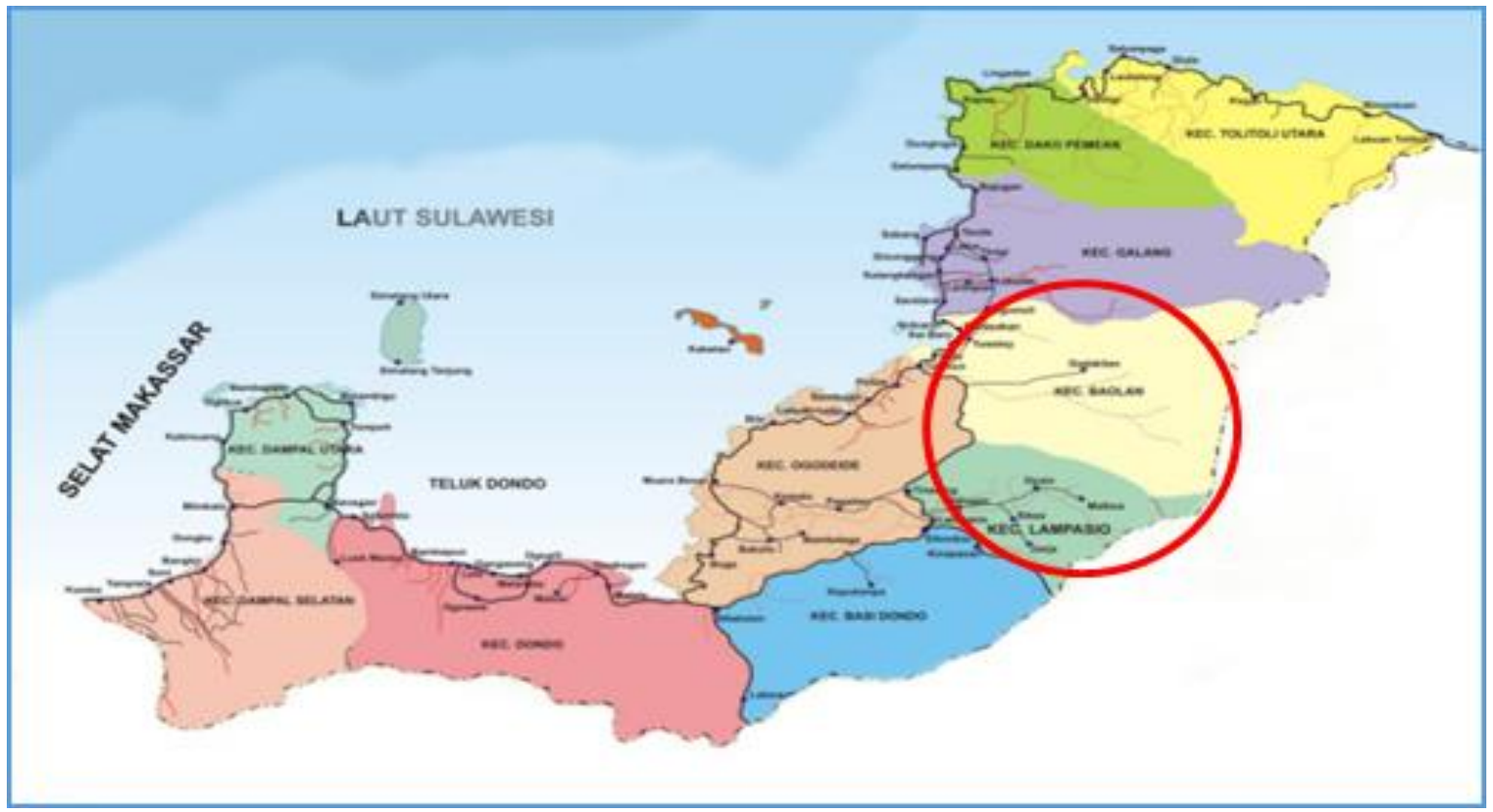

Gambar 1 Peta Kabupaten Tolitoli, Propinsi Sulawesi Tengah per kecamatan. tempat lokasi survei keberadaan pohon gaharu (lingkaran merah, Kecamatan Lampasio dan Baolan).

Culture Collection (IPBCC). Identifikasi pohon gaharu dilakukan di Herbarium Bogoriense, LIPI.

Mitra kegiatan ini ialah penduduk Kecamatan Baolan dan Lampasio yang telah mengenal keberadaan gaharu dan potensinya sebanyak 10 petani pada masing-masing kecamatan. Selain itu, Dinas Kehutanan Kabupaten Tolitoli berperan sebagai penanggung jawab dan pelaksana kegiatan.

\section{Alat dan bahan.}

Alat yang digunakan selama kegiatan: alat tulis, kamera, GPS, alat-gelas, alat pembuatan herbarium, autoklaf, oven, mikroskop, kantong plastik, alat dan mata bor kayu, serta meteran. Bahan yang digunakan untuk praktik bio-induksi ialah alkohol 70\%, media agar kentang, serbuk gergaji, akuades, spiritus, 10 pohon gaharu dengan diameter batang minimal $40 \mathrm{~cm}$, dan cendawan lokal sebagai inokulum.

\section{Metode kegiatan.}

Pengambilan data sekunder: data sekunder yang dicatat adalah data kependudukan, wilayah dan topografi, iklim, dan jenis komoditi pohon yang ditanam oleh petani di Kabupaten Tolitoli.

\section{- Survey lahan dan tanah}

Pada survey lahan dicatat kondisi tempat dan karakteristik fisika dan kimiawi tanah. Untuk memperoleh karakteristik tanah, sampel tanah diambil dari lokasi ditemukannya pohon gaharu sebanyak dua titik di tiap lokasi.

\section{- Eksplorasi keberadaan spesies pohon gaharu}

Pendataan pohon dilakukan di lokasi pohon gaharu tumbuh dan diutamakan yang tumbuh di lahan milik masyarakat setempat dan di hutan yang berdekatan dengan pemukiman. Keberadaan pohon ditelusuri pemiliknya, umur, asal bibit, jumlah pohon per satuan luas, riwayat berbuah, sert bentuk daun dan buah. Contoh daun dan buah disimpan sebagai herbarium untuk identifikasi spesies pohon. Eksplorasi pohon gaharu terutama digunakan untuk menetapkan status pohon sebagai pohon induk yang dapat dijadikan sebagai sumber benih saat penyediaan bibit.

\section{- Eksplorasi sumber inokulum}

Sumber inokulum dilakukan dengan mencari batang pohon gaharu yang terinfeksi dengan ciri adanya lubang, membusuk, dan berwarna hitam. Kayu di sekitar lubang dengan warna hitam dibakar dan bila beraroma wangi maka sampel kayu dari lubang tersebut dikulturkan untuk mendapatkan cendawan yang diduga sebagai pathogen kayu gaharu. Isolasi cendawan dilakukan menggunakan medium PDA (Potato Dextrosa Agar) yang telah diberi antibiotik untuk menghindari kontaminasi oleh bakteri. Sampel serpihan batang pohon gaharu disteril bagian permukaan dengan menggunakan clorox $2 \%$ selama 2 menit sebanyak tiga kali, kemudian dibilas dengan menggunakan akuades steril sebanyak tiga kali. Selanjutnya sampel diletakkan 
ke dalam botol yang telah diberi tissu yang dibasahi dengan akuades dan ditutup dengan alumunium foil selama 24 jam. Sampel selanjutnya diletakkan pada cawan petri yang berisi media PDA yang telah diberi antibiotik untuk menghindari kontaminasi oleh bakteri. Cendawan yang tumbuh dipindahkan ke dalam cawan petri yang berisi media PDA dan diinkubasi pada suhu $25^{\circ} \mathrm{C}$. Cendawan yang telah tumbuh pada media isolasi PDA kemudian dimurnikan satu persatu. Masing-masing isolat murni cendawan yang diperoleh kemudian dipindahkan ke dalam media PDA. Pemurnian ini bertujuan untuk memisahkan koloni dengan morfologi berbeda untuk dijadikan isolat tersendiri. Pengamatan morfologi dilakukan kembali setelah inkubasi selama 5-7 hari, apabila masih ditemukan pertumbuhan koloni yang berbeda secara makroskopik maka harus dipisahkan kembali sampai diperoleh isolat murni. Cendawan diinkubasi pada suhu kamar selama 3-5 hari. Pengamatan dilakukan terhadap warna koloni, konidiofor, dan spora yang dihasilkan. Identifikasi cendawan dilakukan menggunakan kunci identifikasi Barnett \& Hunter (1998).

\section{- Pendataan kondisi sosial ekonomi masyarakat peminat dan pemilik pohon gaharu}

Pengambilan data dilakukan dengan metode deskripsi melalui wawancara dengan masyarakat peminat dan pemilik pohon gaharu. Hal-hal yang ditanyakan berkaitan dengan pekerjaan, pengetahuan tentang produk gaharu, pengalaman mencari, mendapatkan dan menjual produk gaharu, pembibitan, dan penanaman pohon gaharu.

\section{- Pelatihan dan pendampingan}

Pelatihan dilakukan secara tatap muka yang diikuti dengan praktik. Peserta pelatihan ialah aparat pemda, praktisi, pemuka masyarakat, dan petani gaharu. Materi disampaikan oleh narasumber di dalam ruangan maupun di lokasi praktik. Sebelum pelaksanaan progam kegiatan dilakukan sosialisasi program pada jajaran aparat pemda, praktisi, dan pemuka masyarakat Kabupaten Tolitoli. Topik pelatihan dan praktik tersaji pada Tabel 1. Setelah masyarakat dianggap mampu mengenal ciri-ciri pohon gaharu, cara bertanam dan bio-induksi produk gaharu, maka dilakukan pendampingan selama dua tahun terhadap kegiatan yang telah dan akan dilakukan oleh Pemda dan petani gaharu.

\section{- Pelatihan bio-induksi produk gaharu}

Bio-induksi dilakukan dengan menggunakan inokulum cendawan lokal hasil isolasi. Pohon gaharu yang digunakan sebanyak 10 pohon milik petani di Kecamatan Baolan dan Lampasio. Kulit pohon ditandai untuk menentukan posisi lubang yang akan dibuat. Posisi lubang terbawah $\pm 20 \mathrm{~cm}$ dari permukaan tanah. Lubang-lubang penyuntikan dibuat dengan jarak horizontal antar lubang $\pm 10 \mathrm{~cm}$ hingga mengelilingi batang pohon membentuk garis lingkaran, jarak vertikal antara lingkaran $\pm 20 \mathrm{~cm}$. Bor digunakan untuk melubangi pohon dengan kedalaman sepertiga diameter batang. Lubang dibersihkan dari serpihan kayu sisa pengeboran. Inokulum disiapkan dengan cara dipindahkan di atas plastik untuk diratakan kemudian diletakkan di atas plat aluminium. Stik kayu dicelupkan ke dalam alkohol $70 \%$ sebelum digunakan sebagai pendorong inokulum ke dalam lubang. Inokulum dimasukkan ke dalam lubang hingga memadat dan memenuhi lubang. Isolat dimasukkan ke lubang sebanyak 4 lingkaran lubang pengeboran, kemudian kulit pohon diberi label kode isolat dan tanggal bio-induksi.

\section{- Pengamatan hasil bio-induksi}

Hasil bio-induksi diamati tiap bulan dengan kriteria perubahan warna kayu dan aroma. Kayu

Tabel 1 Topik pelatihan dan praktik pengembangan produk dan budidaya gaharu

\begin{tabular}{|c|c|c|c|}
\hline Topik & Metode penyampaian & Tempat & Durasi \\
\hline Pengenalan pohon gaharu dan produknya & Tatap muka dan praktik & Dalam dan luar ruang & 3 hari \\
\hline $\begin{array}{l}\text { Cara bertanam pohon gaharu dan } \\
\text { pemeliharaannya }\end{array}$ & Tatap muka & Dalam ruang & 2 jam \\
\hline $\begin{array}{l}\text { Cara bio-induksi pohon gaharu } \\
\text { menggunakan inokulum lokal }\end{array}$ & Tatap muka dan praktik & Dalam dan luar ruang & 7 hari \\
\hline $\begin{array}{l}\text { Deteksi keberadaan produk gaharu pada } \\
\text { pohon gaharu }\end{array}$ & Praktik & Luar ruang & 6 bulan \\
\hline Evaluasi hasil bio-induksi & Praktik & Luar ruang & 6 bulan \\
\hline Peluang pemasaran & Tatap muka & Dalam ruang & 1 hari \\
\hline Diskusi permasalahan dan peluang & Tatap muka dan praktik & Dalam dan luar ruang & 1 tahun \\
\hline
\end{tabular}


gaharu yang tidak terserang patogen berwarna putih, sedangkan kayu yang merespons cendawan patogen (inokulum) akan berubah warna menjadi putih kecokelatan, cokelat, dan cokelat kehitaman. Kayu yang merespons cendawan patogen (inokulum) akan beraroma wangi bila dibakar.

\section{- Pelatihan pembibitan}

Pembibitan dilakukan di Kecamatan Lampasio. Bibit dan benih yang digunakan berasal dari pohon yang tumbuh di Kecamatan Baolan dan Lampasio. Media tanam yang dipakai berupa tanah. Penyemaian benih dan penanaman bibit dilakukan pada tanah yang diletakkan dalam sungkup plastik hingga tumbuh, kemudian dipindahkan ke lokasi dengan naungan paranet hingga muncul beberapa daun baru.

\section{Analisis data}

Data hasil eksplorasi dan survei berupa data deskriptif dianalisis berdasarkan pengelompokkan, sebaran, dan frekuensi.

\section{HASIL DAN PEMBAHASAN}

Studi kelayakan rekayasa produk gaharu dan budi daya pohon gaharu di Kabupaten Tolitoli diawali dengan sosialisasi program pada jajaran aparat pemda, praktisi, dan pemuka masyarakat Kabupaten Tolitoli (Gambar 2). Sosialisasi program dilakukan untuk mengetahui pemahaman mengenai budi daya dan pengembangan produk gaharu di Kabupaten Tolitoli. Tanggapan masyarakat terhadap program pemberdayaan masyarakat ini sangat baik ditandai dengan keinginan untuk mengetahui dan menjadi pelaku pada program tersebut.

\section{Hasil Analisis Tanah Tempat Pohon Gaharu Tumbuh.}

Tanah yang dianalisis adalah tanah yang berasal dari lahan tempat pohon gaharu tumbuh (Tabel 2). Secara umum kondisi tanah ditempat pertumbuhan gaharu (Kecamatan Lampasio dan Baolan) merupakan tanah dengan tingkat kesuburan baik. Nilai C/N yang berkisar 10-12 merupakan nilai yang tepat untuk menilai kandungan dan kualitas bahan organik tanah (Balai Penelitian Tanah 2009). Kandungan N pada bahan organik yang rendah menunjukkan ciri tanah di daerah tropis. Hal ini dapat diatasi dengan pemberian pupuk pada pertanaman pohon gaharu.

\section{Hasil Eksplorasi Pohon Gaharu}

Survei lahan pohon gaharu di Kabupaten Tolitoli dilakukan di beberapa lokasi di Kecamatan Lampasio dan Baolan. Hasil inventarisasi

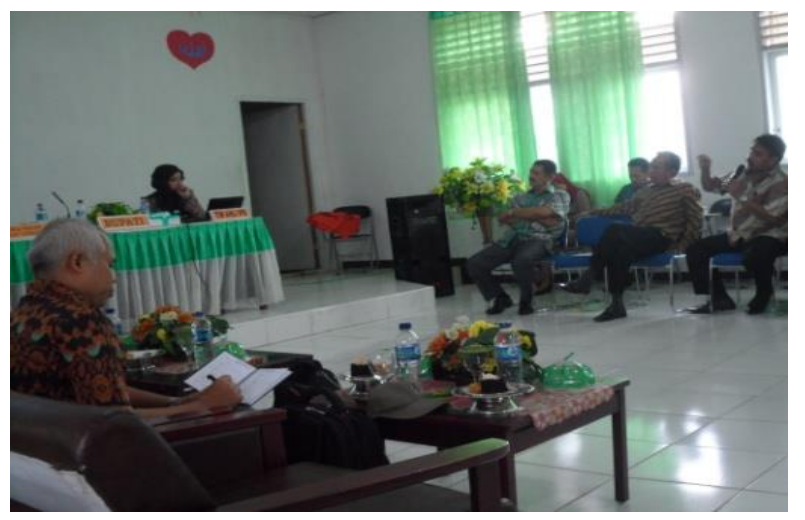

a

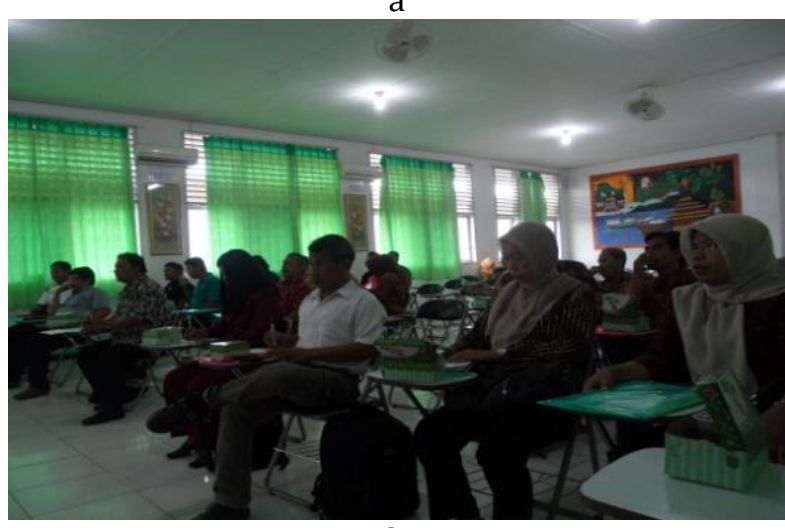

b

Gambar 2 a dan b Sosialisasi program kegiatan pemberdayaan masyarakat untuk budi daya dan pengembangan produk gaharu di Kabupaten Tolitoli.

Tabel 2 Hasil analisis kualitas tanah di lokasi pertanaman gaharu

\begin{tabular}{|c|c|c|}
\hline Parameter & Nilai & Kriteria* \\
\hline Tekstur tanah & & $\begin{array}{l}\text { Lempung } \\
\text { berdebu- } \\
\text { lempung berliat }\end{array}$ \\
\hline $\mathrm{pH}\left(\mathrm{H}_{2} \mathrm{O}\right)$ & $5,50-6,50$ & Agak masam \\
\hline $\mathrm{C} / \mathrm{N}$ & $10,00-12,00$ & Sedang \\
\hline $\begin{array}{l}\mathrm{P}_{2} \mathrm{O}_{5} \text { Olsen } \\
(\mathrm{ppm} \mathrm{P})\end{array}$ & $21,00-61,00$ & Tinggi \\
\hline $\begin{array}{l}\mathrm{K}_{2} \mathrm{O} \text { Morgan } \\
(\mathrm{ppm} \mathrm{K})\end{array}$ & $92,00-263,00$ & Tinggi \\
\hline $\begin{array}{l}\text { KTK (me/100 } \\
\text { g tanah) }\end{array}$ & $22,57-37,04$ & Tinggi \\
\hline
\end{tabular}

$\left({ }^{*}\right)$ Balai Penelitian Tanah, Badan Penelitian dan Pengembangan Pertanian, Departemen Pertanian (2009) 
pohon gaharu pada dua kecamatan tersebut terdapat 9 orang yang memiliki pohon gaharu yang telah beberapa kali berbuah. Pohon gaharu di lokasi-lokasi tersebut mempunyai kesamaan bentuk buah. Berdasar diameter batang, diperkirakan umur pohon gaharu lebih dari 10 tahun. Jumlah pohon gaharu yang ditemukan di sekitar pemukiman diperkirakan 1500 pohon, masing-masing sebanyak 600 pohon tumbuh di Kecamatan Lampasio dan 930 pohon ditemukan di Kecamatan Baolan. Selama ini mereka menjual buah gaharu kepada petani pembibit. Pohon gaharu yang ditemukan di Kecamatan Lampasio dan Baolan (Gambar 3) dimiliki oleh masyarakat setempat terdapat tiga fenotipe dan patut diduga salah satunya sebagai spesies baru. Hal ini didasarkan pada hasil identifikasi di Herbarium Bogoriense, LIPI.

\section{Hasil Eksplorasi Sumber Inokulum untuk Induksi Pembentukan Gaharu}

Hasil eksplorasi sumber inokulum diperoleh dari batang pohon gaharu yang berlubang secara alami dan ada pembusukan kayu yang berwarna cokelat-hitam serta beraroma wangi (Gambar 4). Hasil analisis dan pengamatan di laboratorium bahwa telah ditemukan 9 isolat cendawan dari genus Acremonium sp. dan Fusarium sp. yang berasal dari lubang-lubang tersebut. Isolat cendawan yang diperoleh kemudian disesuaikan dengan aroma wangi asal inokulum tersebut, ternyata diperoleh 3 isolat yang menjadi kandidat sebagai sumber inokulum lokal untuk induksi pembentukan gaharu. Isolat hasil isolasi dan identifikasi diperbanyak untuk digunakan sebagai bahan bio-induksi pembentukan gaharu di Kabupaten Tolitoli (Gambar 5). Marlina et al.
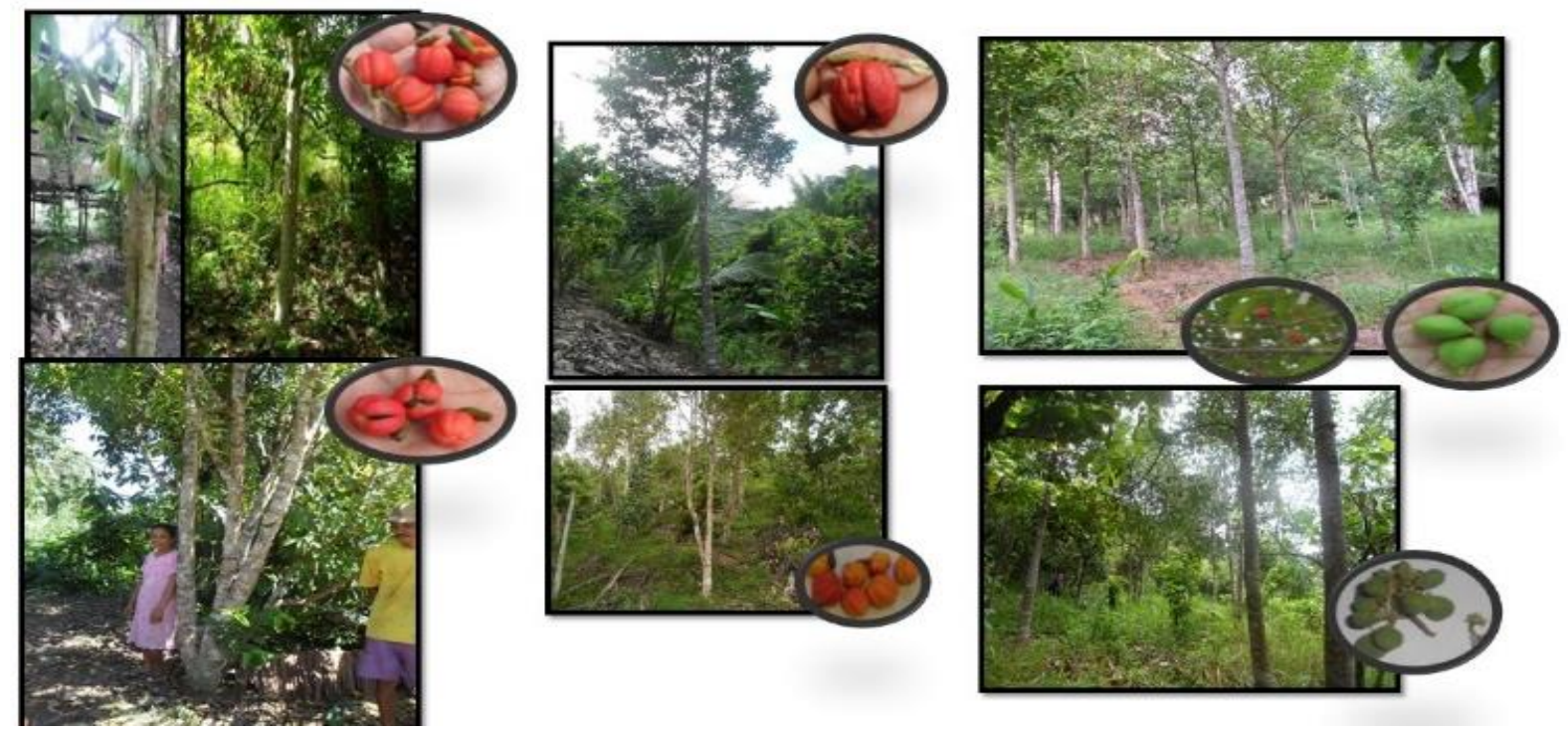

Gambar 3 Ragam pohon gaharu milik masyarakat yang ditemukan di Kecamatan Baolan dan Lampasio, Kabupaten. Tolitoli.
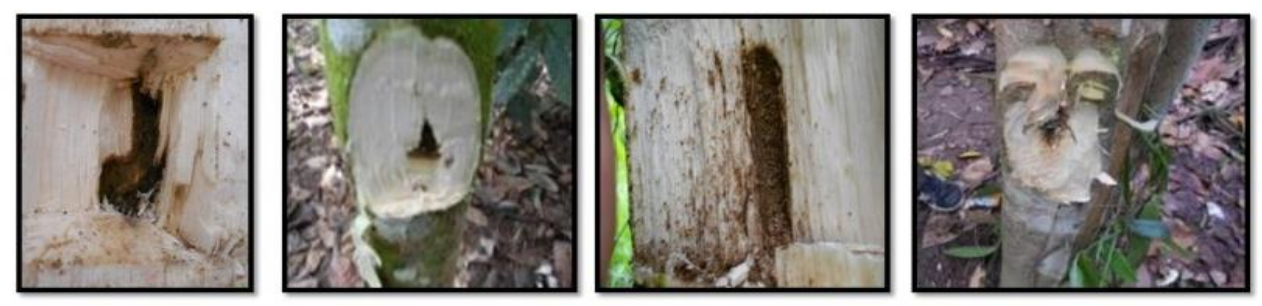

Aroma wangi
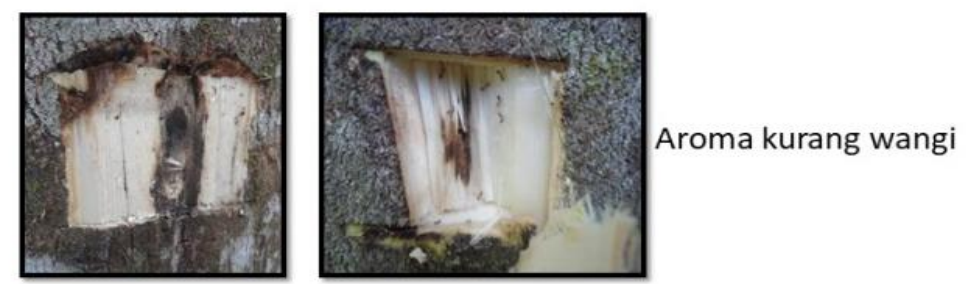

Gambar 4 Lubang-lubang pada batang pohon gaharu yang digunakan untuk analisis sumber inokulum lokal. 

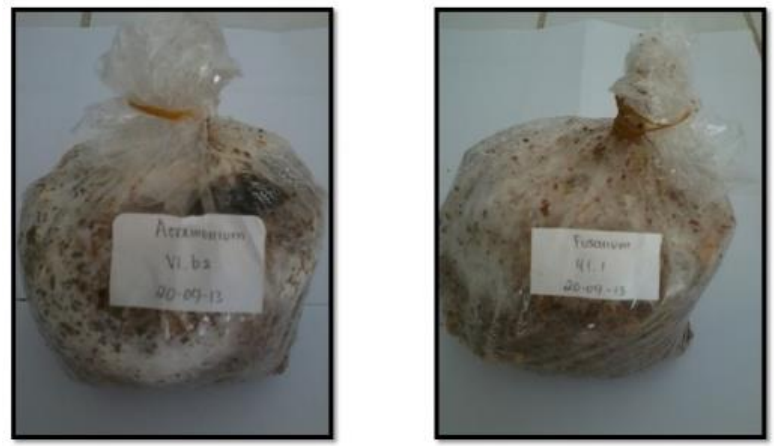

Gambar 5 Isolat Acremonium sp. (kiri) dan Fusarium sp. (kanan) hasil perbanyakan di laboratorium yang akan digunakan untuk bioinduksi pembentukan gaharu.

(2018) telah menggunakan Acremonium sp. untuk memacu pembentukan gaharu dengan cara menyuntikkan pada batang utama pohon gaharu. Selain itu, Triadiati et al. (2016) dan Wahyuni et al. (2018) telah melakukan induksi pembentukan resin gaharu menggunakan cendawan Fusarium yang dalam 3 bulan telah menghasilkan aroma wangi dan perubahan warna kayu. Cendawan yang digunakan untuk memacu pembentukan resin gaharu pada infeksi buatan ialah Fusarium Faizal solani (et al. 2017; Wahyuni et al. 2018).

Pada kegiatan ini digunakan pohon dan inokulum lokal untuk bio-induksi pembentukan gaharu di Kabupaten Tolitoli. Hal ini dilakukan untuk meminimalkan resiko ketidakseimbangan sumber daya alam di kabutapen tersebut. Bagaimanapun juga isolat-isolat cendawan yang berhasil diisolasi merupakan patogen pelapuk batang yang dimungkinkan pada masa yang akan datang dapat berubah virulensinya dan dapat menjadi patogen untuk pohon selain gaharu. Berdasar alasan tersebut, pada kegiatan ini tidak melakukan introduksi inokulum. Pemilihan pohon gaharu lokal yang digunakan untuk diinduksi dengan menggunakan inokulum lokal bertujuan untuk mengoptimalkan hasil pembentukan gaharu, karena secara alami sudah terjadi interaksi antara pohon dan patogennya.

\section{Kondisi Sosial Ekonomi Masyarakat Peminat dan Pemilik Pohon Gaharu}

Tanah pertanian di sekitar daerah survei berpotensi sangat baik untuk pertanian dan perkebunan. Hal ini diindikasikan dengan banyaknya macam pohon buah yang tumbuh dengan subur. Hutan produksi kakao dan cengkeh juga terlihat cukup subur disertai macam-macam pohon kayu produksi dan sumber mata air yang jernih. Dengan tanah yang subur dan hasil bumi yang melimpah, seharusnya kesejahteraan masyarakat sudah memadai. Akan tetapi, kondisi ekonomi masyarakat terlihat kurang memadai, begitu juga dengan sarana dan prasarananya. Beberapa dusun tidak dialiri dengan listrik, sumber listrik didapatkan dari genset dan solar panel tenaga matahari. Kondisi beberapa jalan desa rusak dan tidak beraspal, sehingga saat musim hujan tiba banyak genangan air.

Kondisi di atas dimungkinkan karena tengkulak yang mempermainkan harga cengkeh dan biji kakao. Peran serta pemda diharapkan mampu menjaga stabilitas harga cengkeh, sebagai hasil utama Kabupaten Tolitoli, terutama saat panen besar. Hal yang sama dapat terjadi ketika gaharu telah menjadi salah satu komoditas Tolitoli, sehingga tujuan mesejahterakan masyarakat melalui gaharu tidak tercapai. Oleh karena itu, bio-induksi pembentukan gaharu dengan sumber inokulum lokal asal Tolitoli diharapkan mampu meningkatkan perekonomian masyarakat Kabupaten Tolitoli.

\section{Tingkat Pengetahuan Masyarakat Mengenai Kayu Gaharu}

Hasil diskusi dengan beberapa anggota masyarakat pemilik pohon gaharu didapatkan bahwa tingkat pengetahuan masyarakat Kabupaten Tolitoli terhadap gaharu beragam. Ada penduduk yang hanya menanam pohon gaharu tanpa mengetahui jenis pohon, nilai ekonomi, dan kondisi yang tepat untuk menginisiasi terbentuknya senyawa wangi gaharu.

Selama survei di lapangan ditemukan beberapa potongan kayu gaharu yang didapatkan dari pengumpul gaharu dari hutan (Gambar 6). Uji wangi pada potongan pohon gaharu yang ditebang menunjukkan adanya aroma walaupun bau yang dihasilkan tidak menyengat, sehingga kualitasnya rendah. Lempengan pohon berwarna cokelat muda dan tua disimpan dalam karung plastik. Dari hasil diskusi dengan pemilik-pemilik potongan kayu gaharu terdapat indikasi pengetahuan para penebang minim dalam mengenali kualitas gaharu dan hanya mengandalkan dugaan.

\section{Pelatihan dan Praktik Budi Daya Pohon Gaharu}

Pelatihan dan praktik budi daya pohon gaharu menggunakan benih dan bibit lokal asal Kabupaten Tolitoli (Gambar 7). Penggunaan benih dan bibit cabutan lokal untuk pembibitan gaharu ditujukan agar genotipe gaharu lokal 

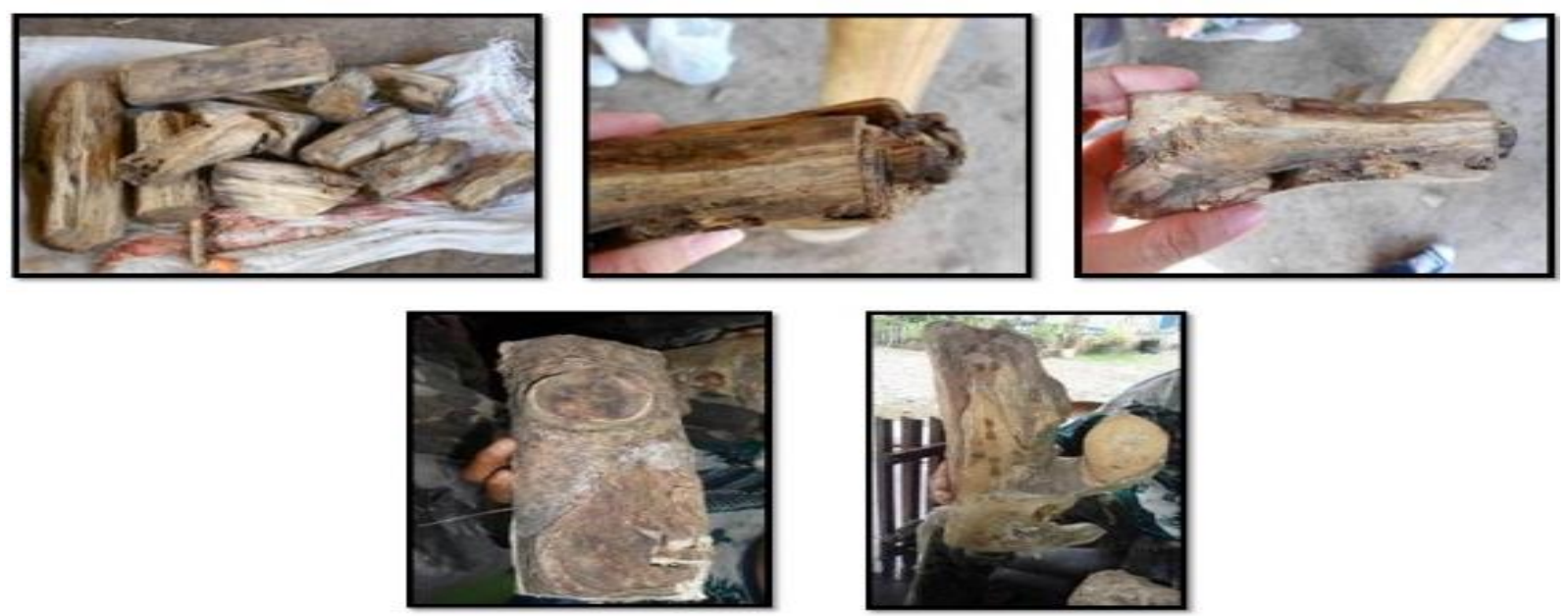

Gambar 6 Kualitas kayu gaharu yang disimpan petani di Kabupaten Tolitoli.

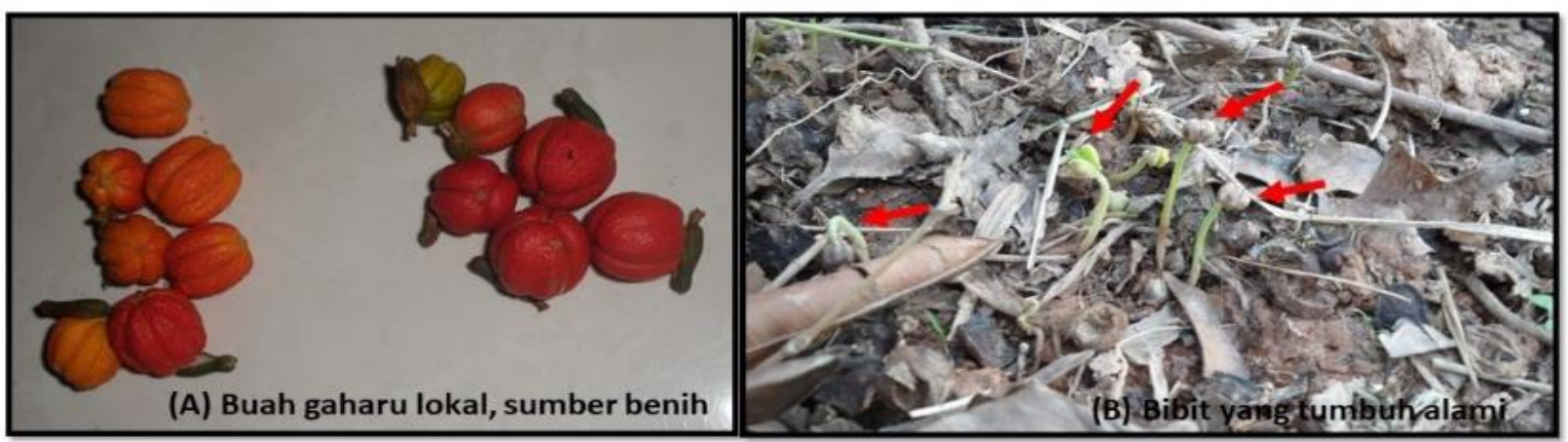

Gambar 7 Sumber benih (A) dan bibit (B) yang digunakan untuk bahan pelatihan. Tanda panah merah merupakan benih-benih yang tumbuh alami di bawah pohon gaharu.

tidak punah. Praktik budi daya dilakukan di salah satu lahan petani gaharu (Pak Kadir) di Kecamatan Lampasio yang diikuti oleh petani-petani gaharu setempat (Gambar 8). Pak Kadir dijadikan sebagai salah satu narasumber, karena telah melakukan pembibitan dengan menggunakan biji dan bibit cabutan lokal.

Benih dan bibit cabutan ditanam dengan media tanam tanah dari sekitar pohon gaharu tumbuh dan diletakkan di bawah sungkup (Gambar 9). Bila benih dan bibit berhasil tumbuh di bawah sungkup hingga tumbuh 2 pasang daun, maka sungkup dibuka, tetapi bibit masih dipelihara di bawah naungan pohon. Bibit siap dipindah tanam ke lahan budi daya pohon gaharu bila telah mencapai tinggi $30-50 \mathrm{~cm}$. Dengan adanya petani yang sudah terampil melakukan pembibitan gaharu (Pak Kadir), maka dapat menjadi pendamping untuk petani-petani lain yang belum terampil.

\section{Pelatihan dan Praktik Bio-Induksi Pembentukan Gaharu pada Pohon Gaharu}

Pelatihan dan praktek bio-induksi dengan cara penyuntikan batang pohon gaharu meng-

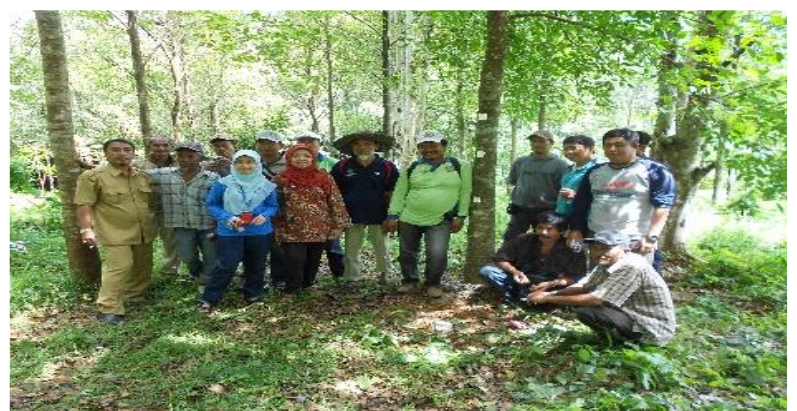

Gambar 8 Sebagian peserta pelatihan dan praktik pembibitan untuk tujuan budi daya pohon gaharu

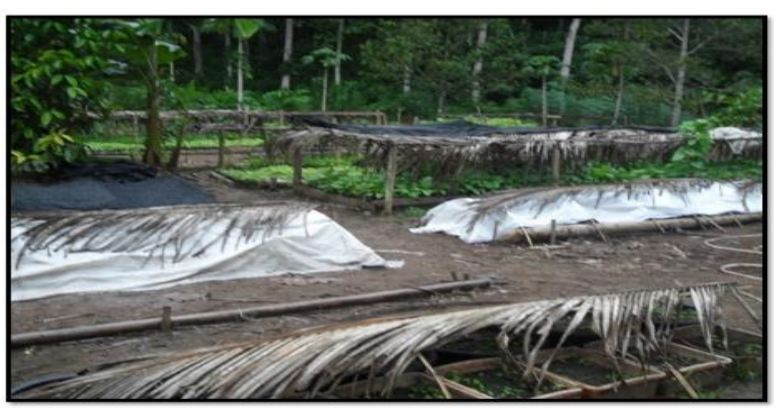

Gambar 9 Sungkup untuk tempat tumbuh benih dan bibit gaharu. 
gunakan inokulum lokal dilakukan di pemilik kebun gaharu (Gambar 10). Pohon yang dipilih ialah pohon dengan diameter batang setinggi dada minimal $\pm 40 \mathrm{~cm}$. Seluruh proses bioinduksi dilakukan oleh petani dan anggota penyuluh lapangan kehutanan secara bergantian.

Pelatihan dan praktik berlangsung dengan baik ditunjukkan dengan minat dan keseriusan peserta petani yang mengikuti kegiatan ini. Kegiatan seperti ini belum pernah dilakukan sebelumnya di Kabupaten Tolitoli. Berdasarkan pengamatan selama pelatihan dan praktik penyuntikan dapat dinilai bahwa perlu dilakukan kegiatan seperti ini secara berulang agar ketrampilan dan pemahaman yang diharapkan dapat dimiliki oleh masyarakat dengan optimal. Wangiyana et al. (2020) telah melakukan pelatihan dan praktek induksi di masyarakat petani gaharu Desa Pejaring, Kabupaten Lombok Timur. Petani gaharu di Desa Pejaring telah memahami dan mampu mengaplikasikan teknologi bioinduksi sebagai pengganti metode tradisional yang selama ini mereka gunakan melalui beberapa kali praktik.

\section{Pengamatan Hasil Induksi Pohon Gaharu}

Pengamatan hasil penyuntikan dilaksanakan oleh perwakilan Litbang PEMDA Kabupaten Tolitoli dan penyuluh kehutanan sesuai format pengamatan yang telah diberikan. Pengamatan terhadap pembentukan gubal (warna kayu dan tingkat wangi kayu ketika kayu dibakar) dilakukan setiap bulan setelah induksi (bsi) selama 6 bulan pada lubang induksi yang berbeda.

Perubahan warna kayu meliputi tingkat perubahan dan luas zona perubahan warna kayu (ukur panjang dan lebarnya). Tingkat perubahan warna kayu ditetapkan berdasarkan sistem skor. Zona perubahan warna kayu dinyatakan dalam panjang dan lebar zona. Tingkat wangi ditetapkan berdasarkan sistem skor dengan cara membakar kayu yang berwarna gelap. Berdasarkan pengamatan hasil bio-induksi adanya perubahan warna dan tingkat wangi menunjukkan bahwa inokulum lokal Tolitoli hasil eksplorasi memberikan respons positif pada proses awal pembentukan gaharu (Gambar 11). Perubahan warna dan aroma pada batang pohon setelah bio-induksi dengan inokulum Fusarium dan Acremonium hampir sama. Pembentukan resin gaharu pada batang pohon gaharu yang diberi inokulum lokal dipengaruhi oleh interaksi antara infeksi inokulum (cendawan) dengan mikroorganisme tanah (Chippa \& Kaushik 2017).

Warna kayu cokelat-hitam setelah diinduksi beraroma wangi. Dengan kondisi ini diharapkan proses pembentukan gaharu tetap berjalan hingga diperoleh inokulum yang terbaik untuk menghasilkan kualitas gaharu yang baik pula. Pembentukan aroma resin gaharu dan perubahan warna kayu gaharu pada proses infeksi buatan menggunakan inokulum dipengaruhi oleh faktor biotik dan abiotik. Faktor biotik terutama cendawan sebagai agen bio-induksi yang menentukan pembentukan resin gaharu harus bersifat endofitik-patogenik-epifitik (Chi et al. 2016; Chippa et al. 2017).

Kegiatan pemberdayaan masyarakat pada pengembangan produk dan budi daya gaharu di Kabupaten Tolitoli diperlukan agar keberadaan pohon gaharu lokal tetap lestari dan dapat menghasilkan produk gaharu dengan kualitas
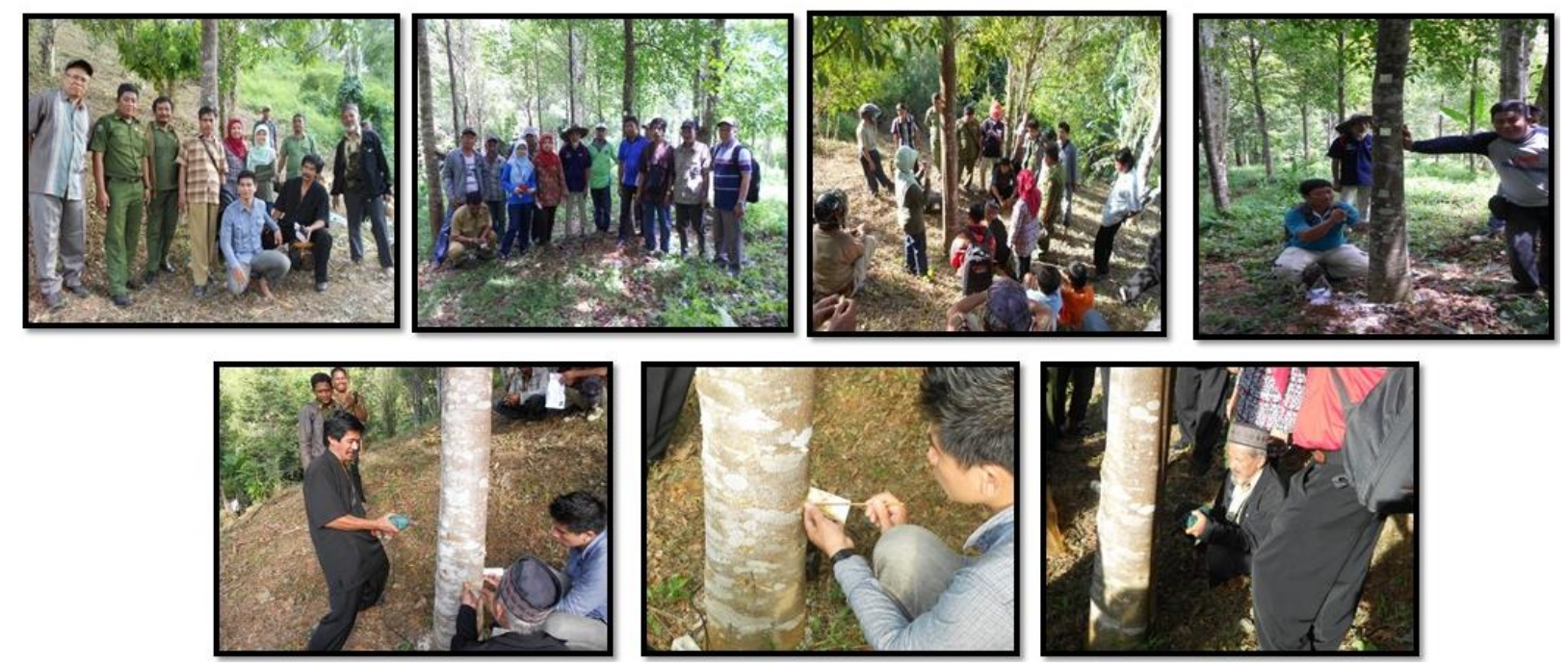

Gambar 10 Pelatihan dan praktek bio-induksi pohon gaharu dengan metode penyuntikan menggunakan inokulum lokal di pohon gaharu milik masyarakat Kabupaten Tolitoli. 
baik. Pemberdayaan masyarakat melalui teknologi produksi gaharu telah dilakukan di beberapa daerah di Sumatera dan Kalimantan dengan hasil yang baik (Siran \& Turjaman 2012). Selain itu,
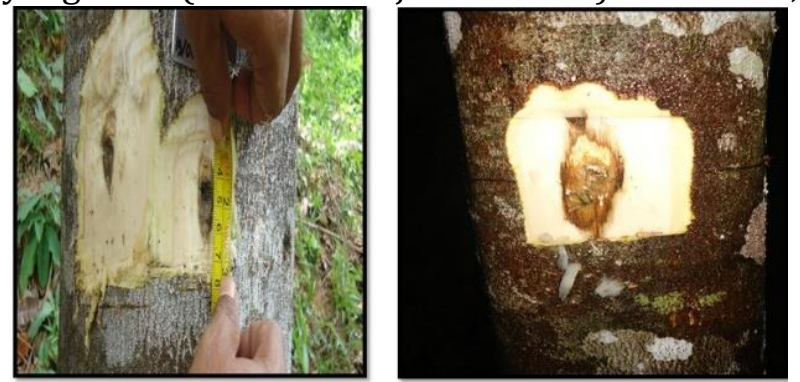

Gambar 11 Hasil induksi pembentukan gaharu pada batang pohon 6 bulan setelah induksi. Cara pengukuran zona yang terdampak oleh induksi inokulum kiri), perbedaan antara warna kayu sehat (putih) dengan kayu yang telah terkena inokulum dan menyimpan resin (cokelat-hitam) (kanan).

berdasar penelitian yang telah dilakukan oleh Surata \& Soenarno (2011); Suhartati \& Wahyudi (2011); Suhartati (2013) bahwa gaharu bisa ditanam dengan beberapa pola pertanaman. Hal ini semakin meningkatkan kemampuan masyarakat dalam program pemberdayaan. Pendampingan terhadap petani gaharu dilakukan hingga tahun 2018 dengan cara komunikasi jarak jauh secara informal untuk memberikan solusi dari permasalahan yang dihadapi.

Keterlibatan dan persamaan persepsi di lingkungan Pemda dibutuhkan untuk mengawal masyarakat Kabupaten Tolitoli dalam membudidayakan pohon gaharu dan inokulum lokal sebagai salah satu komoditas asli daerah untuk menunjang perekonomian masyarakat. Hal ini diperlukan agar keberadaan pohon gaharu yang tumbuh alami dan inokulum lokal untuk bioinduksi di kabupaten tersebut sebagai modal dasar dapat dimanfaatkan dengan baik.

\section{SIMPULAN}

Berdasarkan kegiatan-kegiatan yang dilakukan dapat disimpulkan bahwa di Kabupaten Tolitoli: 1) Ditemukan jenis pohon gaharu yang patut diduga spesies baru dan ditemukan inokulum lokal untuk digunakan pada program infeksi buatan dalam upaya pembentukan resin gaharu; 2) Mempunyai kondisi agroklimat yang sesuai untuk lokasi budi daya tanaman gaharu; 3) Berhasil melakukan pelatihan dan praktek pembibitan gaharu; dan 4) Mempunyai masya- rakat yang siap diberdayakan untuk pengembangan produk gaharu dan budidaya pohon gaharu.

Rekomendasi yang diusulkan bila program tersebut akan dikembangkan menjadi salah satu produk unggulan Pemda Kabupaten Tolitoli yaitu: 1) Perlu adanya persamaan persepsi, konsistensi dan komitmen kuat di jajaran Pemda pada program pengembangan gaharu di Kabupaten Tolitoli agar petani gaharu tidak merasa ditinggalkan dan meminimalkan intervensi pihak lain yang bertujuan mencari keuntungan sepihak dan 2) Perlu disiapkan sarana, prasarana dan aturan untuk mendukung kelestarian dan produk dari pohon gaharu.

\section{UCAPAN TERIMA KASIH}

Ucapan terima kasih disampaikan kepada Pemerintah Daerah Kabupaten Tolitoli yang telah mendanai kegiatan ini melalui APBD tahun 20122014.

\section{DAFTAR PUSTAKA}

Agrios GN. 2005. Plant Pathology. Fifth Edition. USA: Elsevier Academic Press. 922.

Barden A, Anak N, Mulliken T, Song M. 2000. Heart of the matter: Agarwood use and trade and CITES implementation Aquilaria malaccencis. Cambridge (UK): Traffic International.

Barnett HL, Hunter BB. 1998. Illustrated genera of imperfect fungi. ${ }^{4}$ th ed. USA: Prentice-Hall, Inc.

[BSN] Badan Standarisasi Nasional. 1999. SNI 01/5009. 1-1999 Gaharu. Jakarta: Badan Standarisasi Nasional Indonesia.

Balai Penelitian Tanah. 2009. Petunjuk Teknis Analisis Kimia Tanah, Tanaman, Air, dan Pupuk. Balai Besar Badan Litbang Sumberdaya Lahan Pertanian, Badan Penelitian dan Pengembangan Pertanian, Departemen Pertanian.

Chippa H, Kaushik N. 2017. Fungal and bacterial diversity isolated from Aquilaria malaccensis tree and soil, induces agarospirol formation within 3 months after artificial infection. Frontiers in Microbiology. 8: artikel 1286. https: //doi.org/10.3389/fmicb.2017.01286

Chippa H, Chowdhary K, Kaushik N. 2017. Artificial production of agarwood oil in Aquilaria sp. by fungi: a review. Phytochemistry 
Reviews. 16: 835-860. https://doi.org/ 10.1007/s11101-017-9492-6

Chi HK, Hang TTN, Luyen ND, Ha TTH. 2016. Biological characterization of fungal endophytes isolated from agarwood tree Aquilaria crassna Pierre ex Lecomte. Vietnam Journal of Biotecnology. 14(1): 149-156. https: //doi.org/10.15625/1811-4989/14/ 1/9305

Faizal A, Esyanti R, Aulianisa EN, Iriawati, Santoso E, Turjaman M. 2017. Formation of agarwood from Aquilaria malaccensis in response to inoculation of local strains of Fusarium solani. Trees. 31: 189-197. https:// doi.org/10.1007/s00468-016-1471-9

Goodman RN, Kiraly Z, Wood KR. 1986. Secondary metabolites. In: Goodman RN, Kiraly Z, Wood KR. (Eds.): The Biochemistry and Physiology of Plant Disease. Columbia (M0): University of Missouri Press. Page: 211-224.

Marlina M, Riniarti M, Syafe'i R. 2018. The effectiveness of bioserum injection on agarwood resin (Aquilaria malaccensis) formation with several injection hole distances. EnviroScienteae. 14 (3): 222-227. https: //doi.org/10.20527/es.v14i3.5694

Nobuchi T, Siripatanadilok S. 1991. Preliminary observation of Aquilaria crassna wood associated with the formation of aloewood. Bulletin Kyoto University Forest. 63: 226-235.

Siran SA, Maman T. 2012. Pengembangan teknologi produksi gaharu berbasis pemberdayaan masyarakat. Pusat Penelitian dan Pengembangan Hutan dan Konservasi Alam Kampus Balitbang Kehutanan.

Surata K, Soenarno. 2011. Penanaman gaharu (Gyrinops versteegii (Gilg.) Domke) dengan sistem tumpangsari di Rarung, Provinsi Nusa Tenggara Barat. Jurnal Penelitian Hutan dan Konservasi Alam. 8(4): 349-361. https:// doi.org/10.20886/jphka.2011.8.4.349-361

Suhartati, Wahyudi A. 2011. Pola agroforestry tanaman penghasil gaharu dan kelapa sawit. Jurnal Penelitian Hutan dan Konservasi Alam. 8(4): 363-371. https://doi.org/10.20886/ jphka.2011.8.4.363-371

Suhartati. 2013. Budi daya tanaman gaharu (Aquilaria malaccensis Lamrk.) di lahan kebun kelapa sawit dengan aplikasi teknik silvikultur. Info Teknis EBONI. 10(1): 37-47.

Triadiati T, Carolina DA, Miftahudin. 2016. Induksi pembentukan gaharu menggunakan berbagai media tanam dan cendawan Acremonium sp. dan Fusarium sp. pada Aquilaria crassna. Jurnal Sumberdaya Hayati. 2(1): 1-6. $\quad$ https://doi.org/10.29244/ jsdh.2.1.1-6

Wahyuni R, Triadiati T, Falah S. 2018. Induksi pembentukan gaharu pada Aquilaria malaccensis menggunakan pupuk urea dan Fusarium solani. Jurnal Penelitian Kehutanan Wallacea. 7(2): 165-171. https://doi.org/ 10.18330/jwallacea.2018.vol7iss2pp165-171

Wangiyana IGAS, Wanitaningsih SK, Anggadhania L. 2020. Pelatihan teknologi bio-induksi untuk petani gaharu Di desa Pejaring, Kabupaten Lombok Timur. Agrokreatif Jurnal Ilmiah Pengabdian Kepada Masyarakat. 6(1): 36-44. https://doi.org/10.29244/agrokreatif.6.1.3644

Whitmore TC. 1980. An Introduction to Tropical Rain Forests. Oxford (UK): Claredon Press. 